UDC 658.821

JEL Classification: M21

Nefedova A.G.

\title{
ANALYSIS OF ASSESSMENT METHODS OF ENTERPRISE COMPETITIVENESS
}

\author{
Ukrainian State University of Chemical Technology, Dnipro, Ukraine
}

\begin{abstract}
Basic advantages and lacks of modern methods of estimation of enterprises competitiveness, that are based on different methodical principles, carry specific or universal character, are analyzed in the article; inherit or complement other; it is, in opinion of authors, by the complete instrument of estimation or require further development and working. The review of the most widespread modern basic methods of estimation of enterprise competitiveness is given, algorithms over of their estimation (in particular, method of determination of grades, method of effective competition theory, matrix method of estimation, method of construction of polygon of competitiveness, model market «Attractiveness and advantages in a competition», indicatory method on the basis of taking into account of economic and social standards, method of expert's estimation) are brought. Vision of their classification (on four basic descriptions) is given and the lines of certain ideal model is outlined. In the article it is suggested to use fundamental positions are certain: understanding of enterprise as systems of linked elements; research of all complex of factors that determine development of process; in such system must be present the indexes related to the different administrative functions; planning, organization, account and control, reason and stimulation, coordination and adjusting; the specific of production must be taken into account; the separate indexes of the system are called to complement a general picture due to taking into account of influence on the investigated process of specific features of enterprise activity; the created system must contain such indexes the calculation of that can be provided with present in the operating forms of account and statistical accounting information, must take into account possible adjustment of those or other indexes as far as appearance of new data about the object of research or competition environment, that surrounds him. The offered classification removes all modern going near the estimation of competitiveness of enterprise and gives an opportunity to understand their construction and basic differences, exposes advantages and defects and that is why assists scalene deep perception of practical side of enterprises competitiveness.
\end{abstract}

Keywords: method, appraisal, competitiveness, enterprise, principal.

DOI: $10.32434 / 2415-3974-2019-9-1-110-116$

One of the most pressing issues of modern economic science remains competitiveness and its assessment at the enterprise level. Economic science is enriched with various methods of assessing the competitiveness of enterprises, based on various methodological principles; have a specific or universal character; imitate or complement others; is, according to the authors, completed by the evaluation tool or need further development and elaboration. Therefore, the question naturally arises of systematizing accumulated scientific experience.

Analysis and investigation of publications

Attention of many scholars is concerned with assessing the competitiveness of different levels.
Mokronosov A.G. and Mavrin I.N. Having analysed the existing methods of evaluation, distinguish the factors of influence on the level of competitiveness of the enterprise and formulate the basic methodological provisions that should be taken into account when constructing the method of assessing competitiveness [9, 122-142]. Goncharov O.Yu. and Simonova Ye.V. lead methods of assessing competitiveness, but leave the reader the right to independently identify their advantages and disadvantages [2]. Russian authors Akhmatova M.V. and Popov E.V. [1], sufficiently thoroughly analysed methods for assessing the competitiveness of the enterprise, but with time it becomes necessary to 
review the already made, taking into account more relevant information [3-8].

\section{Purpose of the article}

Therefore, the purpose of the article is to analyse and systematize the existing methods of assessing the competitiveness of the enterprise.

\section{Presenting main material}

Existing methods for assessing the competitiveness of an enterprise can be grouped into several groups:

1. According to the degree of complexity:

1) economic;

2) mathematical.

2. By the nature of the resulting indicators:

1) differential;

2) integral.

3. By way of presentation of the final results:

1) analytical;

2) graphic.

4. By valuation method:

1) indicator;

2) expert.

Economic methods of estimation make it possible to assess the level of competitiveness of an enterprise without even using complex mathematical calculations, using only an economic apparatus or using already prepared formulas. The advantages of such methods in the relative ease of use and the speed of obtaining results, and the disadvantages in a large error and low accuracy of the results of the evaluation.

The method consists of the following steps: 1) study of the market, competitors, needs of potential consumers; 2) determining the target segments by directions; 3) definition of the strategic and marketing concept of the firm; 4) the allocation of meaningful blocks, properties and weight coefficients; 5) calculation of the norm of consumer value for the economic unit of properties; 6) calculation of the norm of consumer value for the technical unit of properties; 7) calculation of the norm of consumer value for an ecological unit of properties; 8) calculation of the norm of consumer value for the socio-psychological unit of properties; 9) calculation of the norm of consumer value by the legal unit of properties; 10) definition of the general norm of consumer value of the firm; 11) analysis of the results and decision making on increasing the competitiveness of the enterprise. Positive aspects of this method: the assessment of the competitiveness of the enterprise is based on the assessment of the totality of marketing, managerial and organizational decisions of the firm. This makes it possible to more accurately assess the real needs of potential customers and the level of the company. Disadvantages of this method: to collect all the information necessary for analysis (study of the environment, assessment of factors), only expert methods are used. This does not allow to obtain as objective as possible the indicators of competitiveness, and therefore to objectively determine its level.

Mathematical methods are based on factor models of estimation, which consist in the calculation of one (integral) indicator or several numerical values of indicators on which the final assessment is formed. These methods are considered to be the most accurate, although they sometimes require burdensome mathematical calculations, that is, the special training of employees.

The method of ranking ranks is an example of mathematical methods for assessing the competitiveness of an enterprise. This is a synthetic method for determining the competitiveness of an enterprise, built on the assumption that the competitiveness of the company's products is its main component (in particular, a significant number of other methods for assessing the competitiveness of the enterprise are built on this parcel).

The algorithm of the method is as follows: 1) a list of indicators, which take for the basis of evaluation of the competitiveness of a particular type of products being evaluated, is formed; 2 ) the expert way for each indicator determines its weight in the overall assessment; 3 ) the marketing company of the enterprise is offered a choice of enterprises with similar products, which are the closest competitors; 4) on the basis of the received information, the matrix of determination of the competitiveness of the unit of production of the enterprise being the object of evaluation is built; 5) the absolute values of the selected indicators determine the ranks of the product unit; 6) calculate the weighted weight of the indicator of the total rank of the product unit of each enterprise involved in the assessment array; 7) after the establishment of general rank, the enterprise leader and outsider enterprise are found. The range of outsider distance from the leader gives an idea of the demarcation of enterprises in a competitive environment; 8) determine the competitiveness of the product unit further; 9) to determine the competitive status of the enterprise in the entire range of products that it produces, it is necessary to conduct similar calculations for all types of products, and then summarize the results in the summary table. This method has the basic disadvantages: 1) takes into account only one of many components of the competitiveness of the enterprise - production; 2) requires a large number of calculations; 3 ) at different enterprises (through the use of their own experts) the same data will receive different results. Advantages: 1) does not require the involvement of external experts; 2) in the conditions of limited information about competitors and the availability of only their products, it is possible to determine 
their own place on the market.

Differential methods of constructing competitiveness indicators suggest a comparison of the original features of the objects of comparison with the following summary of the results of comparisons in some general indicator of competitiveness. The result obtained in this way, as a rule, accumulates only certain competitive advantages, namely, the difference in the state of individual factors. Usually in their city, such indicators are not indicators that characterize the results of the competition. This role should be performed by comparative, relative indicators (for example, indices of the results of competing objects). But such an indicator as the market share occupied by the enterprise concerned is comparative in itself and therefore can directly act as an integral indicator of competitiveness [1, p.31]. Disadvantages of this technique: 1) the market share is usually determined by only one (main) product, therefore, the ability to compete for other. products - not taken into account; 2) market share characterizes the place of the company in the market, and therefore - not competitive ability, and competitive status.

Integral methods, in contrast to differential, provide for the construction of general indicators of competitiveness on the basis of meaningful from the production and economic point of view of the models of performance indicators as functions of factors of competitiveness. Unlike differential, such methods allow to compare large arrays of signs of objects of direct comparison (without the comparison between the same names of initial signs of these objects) because of the result indicators integrating in their values the combined effect of these factors.

Analytical methods of evaluation - it should be noted that there are different options for such assessments, depending on the purpose of the competitive analysis and the amount of available information. It does not provide, as a rule, means of increasing the visibility of the resulting information evaluation and the complexity of calculations can approach mathematical, so among the shortcomings - the complexity of calculation and perception. Advantages - such methods often enable not only the assessment of the state of competitiveness for a specific date, but also give the opportunity to develop strategic measures to improve this state. An example of an analytical method is to assess the competitiveness of an enterprise on the basis of effective competition $[1,6,9]$. According to this theory, the most competitive are those enterprises where the best work of all units and services is organized. The efficiency of each of the services is influenced by many factors - the resources of the firm. Evaluating the effectiveness of each department involves assessing the effectiveness of the use of these resources. The basis of the method is the assessment of four group indicators or criteria of competitiveness.

The first group includes indicators that characterize the efficiency of management of the production process: the cost of production costs, the rationality of the exploitation of fixed assets, the perfection of the technology of manufacturing goods, organization of work in production. The second group combines indicators that reflect the efficiency of managing working capital: the independence of the enterprise from external sources of funding, the ability of the company to pay off its debts, the ability to stable development of the enterprise in the future. The third group includes an indicator

\section{Advantages}

The given rating of competitiveness of the enterprise covers all the most important estimations of economic activity of the industrial enterprise; availability of formalized calculation algorithm. Disadvantages The method does not take into account the specifics of enterprises of different directions of activity, where the weight of these factors is different.

Graphic evaluation methods are often used along with analytical ones, then they, in addition to one unit, illustrate the picture of the competitiveness of the enterprise. The disadvantages of graphic methods are that they often show not the competitiveness of the enterprise, but its state among competitors, and the advantages in the presence of formalized evaluation algorithm and the highest level of perception of the final results of the evaluation, interpreted in graphic objects (drawings, charts, diagrams, etc.) The most common and widely used method is the construction of a polygon of competitiveness. Construction of polygons of competitiveness, representing graphic combinations of estimates of the position of the company and competitors in the most significant areas of activity, presented in the form of vector axes. By imposing the polygons of the competitiveness of different enterprises on one another, it is possible to identify the strengths and weaknesses of one enterprise in relation to another. For the quantitative expression of characteristics, an expert method or method of applying scales is used. Most often use a seven- or fifteen-point scale. The main drawbacks of this method are: application of the expert method, that is, the introduction of subjective assessment; difficulties in quantifying such qualitative characteristics as after-sales service, etc.; this method does not give an accurate quantitative assessment of the characteristics of enterprises according to the given criteria. Positive aspects of this method: clearly shows the weak and strong sides of enterprises; allows it to quickly and easily determine the position of the investigated enterprise with respect to its competitors. 
Another approach to illustrating the results of the evaluation is the model «Market Attractiveness - Benefits of Competition». Defining the model is the attractiveness of the market and the benefits of competition. The attractiveness of the market consists of the characteristics of the market space, the quality of the market, the basis of supply and other conditions. The advantages in competition are determined by the relative position in the market, the potential of the product, research potential, as well as the qualifications of managers and employees. This matrix allows you to determine the position of the enterprise in the market relative to other competitors, and also allows you to develop strategic recommendations for improving the competitiveness of the firm. Disadvantages of the model: determining the factors of the model requires a large amount of information, which often is simply not available; it is difficult to quantify the qualitative characteristics; The model is static and reflects only the given time interval.

Indicator methods are based on the use of a system of indicators, which help to assess the competitiveness of the enterprise. Under the indicator are understood a set of characteristics that enable to formally describe the state of the parameters of an object under study, and on this basis formulate recommendations for improving the effectiveness of the operation of the object. Each indicator can break up into a number of indicators that reflect the state of individual elements of the object being studied, therefore, it is often the task of selecting the most important indicators to evaluate each of these factors.

Fedonin OS, Repin I.M., Oleksyuk OI, offer an indicator method for assessing the competitiveness of enterprises by economic and social standards.

Different ratios of income and earnings (capital, labour, time) compared with similar standards, which are determined by the criterion-expert way, give an opportunity to assess the competitiveness of the enterprise. Such an assessment is formed on the basis of the use of a number of indicators and standards (norms, standards), for which the enterprise becomes competitive. The competitiveness standards of the enterprise are divided into two groups: economic and social.

The assessment of the company's competitiveness according to economic standards is carried out by at least 5 economic standards, namely: the efficiency of the use of real and informational resources, economic space, time, technology, income level. Based on these indicators, you can choose the proper methodology for estimating

These indicators are compared with similar normative or actual indicators of competitors, which enables to assess the individual level of competitiveness of the enterprise according to economic standards.

In relation to the established level of competitiveness of the enterprise, depending on the globalization of research objectives, the matrix of competitiveness of the enterprise is constructed, which shows the relative values $\dagger$ of the selected standards (indicators) and their percentage-ballroom expression.

The results of the calculations are summarized in the table for choosing a strategy for improving the competitiveness of the enterprise.

The advantages of this method are that it gives an opportunity to integrate assessment of the competitiveness of the enterprise, taking into account economic and social blocks, and the disadvantages is that expert (ball) assessment methods are predominantly used to develop standards; the authors are proposed to use for comparison the normative or actual figures of competitors without the corresponding proposal of normative industry indicators in the conditions of strict confidentiality of commercial information.

Expert evaluation methods are often used, moreover, as we see, not only as an independent method, but also as an auxiliary in other methods. The essence of these is the involvement of professional experts to assess the competitiveness of the enterprise.

Advantages - in the simplicity of using and saving time in collecting information about competitors, because they are based on the opinion of experienced professionals. However, the advantage of the methods is at the same time a disadvantage for them, because sometimes expert subjectivity may distort the evaluation results depending on the qualifications of experts [3, p.55].

The assessment of competitiveness consists in the compilation of relevant tables, the evaluation of indicators and their comparison with enterprisescompetitors. In this case, as a rule, the assessment is conducted on the following groups of factors: 1) product (product range and nomenclature as a whole, marketing opportunities of new products, basic technology of production, technical and economic indicators of products, product quality, trademark image, industrial design, packaging, certificate of conformity, after-sales service, warranty period, legal product protection); 2) price (selling and consumption price, percentage of price discount, mechanism and terms of payment, conditions for granting a loan); 3) distribution of goods (distribution forms, work of wholesale intermediaries, work of sales representatives, direct delivery, work of retailers, exhibition and fair activity, other factors: degree of coverage of the market, warehousing, transportation, stock control); 4) commodity goods (advertising, PP, sales promotion, direct sales, quality of work of the 
trading apparatus, etc.). Disadvantages of the model: the comparative nature of the estimates, therefore the result is not competitive ability, but competitive status; the selection of evaluation factors is more towards the assessment of the goods, and not the enterprise. Advantages: does not require the use of confidential information, sufficiently qualified experts.

Expert methods are used to assess the competitiveness of enterprises and as an independent method, and as an additional. Therefore, we consider it necessary to pay attention to the following:

1) the quality of the evaluation will directly depend on the qualifications of the experts and the terms of the interview (individual or group);

2) the result of the evaluation can be different (even significant) in different time slices

3) expert opinions may turn out to be diametrically opposed.

In addition, the selection of experts is determined by the possibilities of the enterprise (financial, temporal, spatial, etc.) and significantly influences the outcome of the assessment. Therefore, without deleting this (often quite effective) method of evaluation, we warn against its ill-considered use.

It is advisable to take into account a number of principal methodological provisions when developing the methods for evaluating competitiveness [9, p.123]:

- the principle of system. This principle is based on the notion of a system, when the behaviour of each of its elements affects the behaviour of the whole. Such a whole supports the system of factors of competitiveness of the enterprise, which manifests itself as a result of the interaction of a complex of external and internal conditions of competition;

- the principle of integrated assessment of factors. Since each indicator of a system is a quantitative estimate of the influence on this process of any factor or group of factors, then the whole system of logically interconnected and complementary indicators must be built in accordance with a set of factors that determine the growth of competitiveness of the enterprise. This means that the development of these indicators should precede the study of the whole complex of factors that determine the development of the process being studied;

- the principle of functional management orientation. Due to the fact that the purpose of developing a system of indicators is to manage the process of increasing the competitiveness of the enterprise, in such a system must be present indicators associated with different management functions: planning, organization, accounting and control, motivation and stimulation, coordination and regulation ;

- the principle of taking into account the specifics of production. The developed system should include indicators that reflect the specific industry features of production and take into account their impact on the competitiveness of the enterprise;

- the principle of hierarchy of indicators. Indicators that organically fill this system must be ranked in importance. The separation of the leading components of the process under study should be facilitated by a combination of generalization indicators that provide the most complete, optionally integrated characteristic of the main areas of increasing competition;

- the principle of information security. The system to be created should contain such indicators, the calculation of which can be provided by the available forms of accounting and statistical reporting with information that has the completeness, authenticity, accuracy and timeliness of the accession;

- the principle of ensuring comparability. Construction of the system should be made taking into account compliance with the conditions of comparability of indicators by their characteristics, timing, methods of obtaining information, units of measurement and methods of calculation;

- the principle of continuity. Takes into account the possible correction of these or other indicators as new data about the object of research or the surrounding environment surrounds it. In this case, such an adjustment should be discrete, and its need can only be established by the results of the practical use of the system of indicators being developed.

\section{Conclusions}

The proposed classification reflects all modern approaches to assessing the competitiveness of the enterprise and allows them to understand their construction and main differences, reveals the advantages and disadvantages and, therefore, contributes to the versatile profound perception of the practical side of the competitiveness of enterprises.

An overview of modern methods according to the given classification allows to draw the following conclusions:

1) none of the above techniques is flawless and has both advantages and disadvantages (in particular, based on the assumption that information about competitors is completely accessible, not taking into account the factor of commercial secrecy);

2) the two most common mistakes in assessing the competitiveness of an enterprise are its identification with the competitive status of the enterprise or the competitiveness of the product (goods) of the enterprise, while the product is only one of the components of the competitiveness of the enterprise;

3) the vast majority of methods use more or 
less expert methods of evaluation, which worsens the quality of the results through a certain proportion of subjectivity;

4) the vast majority of techniques are aimed at determining the competitive status, not the potential of the enterprise;

5) the most perfect and qualitative method can be considered that:

- is analytical in nature and reflects the change of competitiveness over a long period of time;

- is an assessment of the ability to compete, that is, the assessment of the competitive potential;

- Provides strategic guidelines for improving this situation;

- has a formalized evaluation algorithm based on economic and mathematical modelling and at the same time is not too complicated in application;

- constructed on the basis of economic indicators and has an integral character;

- provides a graphical interpretation of the results obtained.

\section{REFERENCES}

1. Akhmatova M.V. Theoretical Models of Competitiveness // Marketynh. - 2003. - № 4. - P.25-39.

2. Honcharov A.Iu., Symonova E.V. Methods of assessing the competitiveness of economic systems // Vestnyk ekonomyst ZABHU. - 2014. - Vol. 9. - Rezhym dostupu: http://vseup.ru.

3. Hranaturov V.M., Korablynova Y.A. Managing the Competitiveness of Enterprises: Educational // Odessa: ONAS. $-2016$.

4. Klimenko I.M. Genesis of the Essence and Definition of the Concept of Competitiveness of an Enterprise // Ekonomycheskyi Vestnyk Un-ta: Sb. nauch. trudov uchyjnykh y aspyrantov. - 2017. - Vol. 246. - № 31/1. - P.143-150.

5. Competitiveness of enterprises: assessment of the level and directions of improvement // Za zah. red. O.H. Yankovskoho. - Odessa: Atlant, - 2013. - P.39.

6. Kudosh E.V. Improving the Methods of Assessing the Competitiveness of Regions // Ufa: Yzvestyia Ufymskoho hos. ekon. un-ta. - 2017. - Vol. 39. - № 4. - P.66-78.

7. Kuladzhy T.V. Matrix model of estimation of individual products competitiveness in a cluster // Nauch. prakt. konferentsyy "Ynnovatsyonnye klastery $\mathrm{v}$ tsyfrovoi ekonomyke: teoryia y praktyka" Saint Petersburh: Trudy nauch. prakt. konferentsyy (SPb. 17-22.05.2017). - 2017. - P.526-536.

8. Levakhyna Elena Vladymyrovna. Evaluation of enterprise competitiveness on the local segment of the commodity market: 08.00.05. - Avtoreferat dyssertatsyy na soyskanye uch. step. kand. ekon. Nauk. -2016.

9. Mokronosov A.N., Mavryna Y.N. Competition and competitiveness: a manual. - Ekaterynburh: Yzd-vo Ural un-ta, $-2014 .-39 \mathrm{p}$.

Received 8.04.2019

Reviewer: Prof. Kolesnikov V.P.

\section{АНАЛІЗ МЕТОДІВ ОЦІНЮВАННЯ КОНКУРЕНТОСПРОМОЖНОСТІ ПІДПРИЕМСТВА \\ Нефедова О.Г.}

У статті проаналізовано основні переваги і недоліки сучасних методів оцінювання конкурентоспроможності підприємств, що трунтуються на різних методичних засадах, носять специфічний або універсальний характер; наслідують чи доповнюють інші; $\epsilon$, на думку авторів, закінченим інструментом оцінювання або потребують подальщого розвитку й опрацювання. Подано огляд найбільш розповсюджених сучасних основних методів оцінювання конкурентоспроможності підприємства, наведено алгоритми їх оцінювання (зокрема, метод визначення рангів, метод теорії ефективної конкуренції, матричний метод оцінювання, метод побудови багатокутника конкурентоспроможності, модель "Привабливість ринку переваги в конкуренціі”, індикаторний метод на основі врахування економічних і соціальних стандартів, метод екпертного оцінювання). Надано бачення їх класифікації (за чотирма основними характеристиками) і окреслено риси певної ідеальної моделі. У статті запропоновано використовувати певні принципові положення: розуміння підприємства як системи взаємопов 'язаних елементів; дослідження усього комплексу чинників, що визначають розвиток процесу; в такій системі мають бути присутніми показники, пов'язані з різними управлінськими функціями; плануванням, організацією, обліком і контролем, мотивуванням і стимулюванням, координацією і регулюванням; повинна враховуватись специфіка виробництва; окремі показники системи покликані доповнювати загальну картину за рахунок врахування виливу на досліджуваний процес специфічних особливостей діяльності підприємства; створювана система повинна містити такі показники, розрахунок яких може бути забезпечений наявною в діючих формах обліку і статистичної звітності інформацією, має враховувати можливе коригування тих або інших показників за мірою появи нових даних про об'єкт дослідження або конкурентне середовище, що його оточує. Запропонована класифікація відбиває усі сучасні підходи до оцінювання конкурентоспроможності підприємства $i$ дає змогу зрозуміти їх побудову й основні відмінності, розкриває переваги і недоліки і тому сприяє різнобічному глибокому сприйняттю практичного боку конкурентоспроможності підприємств.

Ключові слова: метод, оцінювання, конкурентоспроможність, підприємство, принцип.

\section{АНАЛИЗ МЕТОДОВ ОЦЕНКИ КОНКУРЕНТОСПОСОБНОСТИ ПРЕДПРИЯТИЯ}

\section{Нефедова А.Г.}

В статье проанализированы основные преимущества и недостатки современных методов оценки конкурентоспособности предприятий, которые основываются на разных методических принципах, носят специфический или универсальный характер; наследуют или дополняют друг друга; являются, по мнению авторов, законченным инструментом оценки или требуют дальнейшего развития и доработки. Подан обзор наиболее распространенных современных основных методов оценки конкурентоспособности предприятия, приведены алгоритмы их оценки (в частности, метод определения рангов, метод теории эффективной конкуренции, матричный метод оценки, метод построения многоугольника конкурентоспособности, модель «Привлекательность рынка - преимущества в конкуренции», индикаторный метод на основе учёта экономических и социальных стандартов, метод екпертной оценки). Предоставлено видение их классификации (по четырем основным характеристикам) и поданы черты некой идеальной модели. В статье предложено использовать определённые приниипиальные положения: понимание предприятия как системы взаимоувязанных элементов; исследование всего комплекса факто- 
ров, которые определяют развитие процесса; в такой системе должны присутствовать показатели, связанные с разными управленческими функциями; планированием, организацией, учетом и контролем, мотивацией и стимулированием, координацией и регулированием; должна учитываться специфика производства; отдельные показатели системы призваны дополнять общую картину за счет учёта влияния на исследуемый процесс специфических особенностей деятельности предприятия; создаваемая система должна содержать такие показатели, расчет которых может быть обеспечен имеющейся в действующих формах учета и статистической отчетности информацией, должен учитывать возможную корректировку тех или других показателей по мере появления новых данных об объекте исследования или конкурентной среде, которая его окружает. Предложенная классификация отражает все современные подходы к оценке конкурентоспособности предприятия и дает возможность понять их построение и основные отличия, раскрывает преимущества и недостатки и потому способствует разностороннему глубокому восприятию практической стороны конкурентоспособности предприятий.

Ключевые слова: метод, оцінка, конкурентоспособность, предприятие, принцип.

\section{ANALYSIS OF ASSESSMENT METHODS OF ENTERPRISE COMPETITIVENESS}

Nefedova A.G. *

Ukrainian State University of Chemical Technology, Dnipro, Ukraine

\section{* e-mail: iop521024@ukr.net}

Basic advantages and lacks of modern methods of estimation of enterprises competitiveness, that are based on different methodical principles, carry specific or universal character, are analyzed in the article; inherit or complement other; it is, in opinion of authors, by the complete instrument of estimation or require further development and working. The review of the most widespread modern basic methods of estimation of enterprise competitiveness is given, algorithms over of their estimation (in particular, method of determination of grades, method of effective competition theory, matrix method of estimation, method of construction of polygon of competitiveness, model market "Attractiveness and advantages in a competition», indicatory method on the basis of taking into account of economic and social standards, method of expert's estimation) are brought. Vision of their classification (on four basic descriptions) is given and the lines of certain ideal model is outlined. In the article it is suggested to use fundamental positions are certain: understanding of enterprise as systems of linked elements; research of all complex of factors that determine development of process; in such system must be present the indexes related to the different administrative functions; planning, organization, account and control, reason and stimulation, co-ordination and adjusting; the specific of production must be taken into account; the separate indexes of the system are called to complement a general picture due to taking into account of influence on the investigated process of specific features of enterprise activity; the created system must contain such indexes the calculation of that can be provided with present in the operating forms of account and statistical accounting information, must take into account possible adjustment of those or other indexes as far as appearance of new data about the object of research or competition environment, that surrounds him. The offered classification removes all modern going near the estimation of competitiveness of enterprise and gives an opportunity to understand their construction and basic differences, exposes advantages and defects and that is why assists scalene deep perception of practical side of enterprises competitiveness. principal.

\section{REFERENCES}

1. Akhmatova, M.V. (2003). Teoretycheskye modely konkurentosposobnosti. Marketynh. [Theoretical Models of Competitiveness] № 4. pp. 25-39 [in Russian].

2. Honcharov, A.Iu. (2014) Metody otsenky konkurentosposobnosti ekonomycheskykh sistem [Methods of assessing the competitiveness of economic systems] [Elektronnyi resurs] / A. Iu. Honcharov, E.V. Symonova // Vestnyk ekonomyst ZABHU.Vol. 9. - Rezhym dostupu: http://vseup.ru [in Russian].

3. V.M. Hranaturov, Y.A. Korablynova (2016). Upravlenye konkurentosposobnostiu predpryiatyi: uchebn. posob. [Managing the Competitiveness of Enterprises: Educational] Odessa: ONAS [in Russian].

4. Klimenko, I. M. (2017) Henezys sutnosti y opredelenyia poniatyia konkurentosposobnosty predpryiatyia [Genesis of the Essence and Definition of the Concept of Competitiveness of an Enterprise] // Ekonomycheskyi Vestnyk Un-ta: Sb. nauch. trudov uchyjnykh y aspyrantov. 246. Vol. №31/1. pp. 143-150 [in Russian].

5. Konkurentospromozhnist pidryiemstva: otsinka rivnia ta napriamy pidvyshchennia: Stenohrafyia. [Competitiveness of enterprises: assessment of the level and directions of improvement] Za zah. red. O.H. Yankovskoho (2013). - Odessa: Atlant, p 39 [in Russian].

6. Kudosh, E. V. (2017) Sovershenstvovanye metodov otsenky konkurentosposobnosty rehyonov [Improving the Methods of Assessing the Competitiveness of Regions] Ufa: Yzvestyia Ufymskoho hos. ekon. un-ta. Vol. №4. - pp. 66-78 39 [in Russian].

7. Kuladzhy, T. V. (2017) Matrychnaia model otsenky konkurentosposobnosty yndyvydualnoi produktsyy $\mathrm{v}$ klastere [Matrix model of estimation of individual products competitiveness in a cluster]. Nauch. -prakt. konferentsyy "Ynnovatsyonnye klastery v tsyfrovoi ekonomyke: teoryia y praktyka" Saint Petersburh: Trudy nauch. -prakt. konferentsyy (SPb. 17-22.05.2017). Pp. 526-536 [in Russian].

8. Levakhyna Elena Vladymyrovna (2016) "Otsenka konkurentosposobnosty predpryiatyia na lokalnom sehmente tovarnoho rynka" [Evaluation of enterprise competitiveness on the local segment of the commodity market] (08.00.05 - Ekonomyka y upravlenye narodnym khoziaistvom: ekonomyka, orhanyzatsyia y upravlenye predpryiatyiamy, otrasliamy, kompleksamy (promyshlennost')). Avtoreferat dyssertatsyy na soyskanye uch. step. kand. ekon. Nauk [in Russian].

9. A.N. Mokronosov, Y. N. (2014) Mavryna Konkurentsyia y konkurentosposobnost': uchebnoe posobye [Competition and competitiveness: a manual]. Ekaterynburh: Yzd-vo Ural un-ta, p. 39 [in Russian]. 